University of Warwick institutional repository: http://go.warwick.ac.uk/wrap This paper is made available online in accordance with publisher policies. Please scroll down to view the document itself. Please refer to the repository record for this item and our policy information available from the repository home page for further information.

To see the final version of this paper please visit the publisher's website. Access to the published version may require a subscription.

Author(s):Christopher Browning and Marko Lehti

Article Title: Beyond East-West: Marginality and National Dignity in Finnish Identity Construction

Year of publication: 2007

Link to published version: http://dx.doi.org/10.1080/00905990701475103

Publisher statement: None 


\section{Beyond East-West: Marginality and National Dignity in Finnish Identity Construction}

Christopher Browning \& Marko Lehti

School of Politics, International Tampere Peace Research Institute, Relations and Philosophy (SPIRE), Yliopistonkatu 58-60 A, Keele University,

Keele 33014 University of Tampere,

Staffordshire, Tampere ST5 5BG, UK

c.browning@intr.keele.ac.uk

marko.lehti@uta.fi 


\section{Beyond East-West: Marginality and National Dignity in Finnish Identity Construction}

\section{'Mindscapes of Marginality'}

Since the end of the Cold War it has become common for Finnish academics and politicians alike to frame debates about Finnish national identity in terms of locating Finland somewhere along a continuum between East and West (e.g., Harle and Moisio 2000). Indeed, for politicians properly locating oneself (and therefore Finland) along this continuum has often been seen as central to the winning and losing of elections. For example, the 1994 referendum on EU membership was largely interpreted precisely as an opportunity to relocate Finland further to the West (Jakobson 1998, 111; Arter 1995). Indeed, the tendency to depict Finnish history in terms of a series of 'westernising' moves has been notable, but has also betrayed some of the politicised elements of this view (Browning 2002). However, this framing of Finnish national identity discourse is not only sometimes politicised, but arguably is also too simplified and results in blindness towards other identity narratives that have also been important through Finnish history, and that are also evident (but rarely recognised) today as well. In this article we aim to highlight one of these that we argue has played a key role in locating Finland in the world and in formulating notions of what Finland is about, what historical role and mission it has been understood as destined to play, and what futures for the nation have been conceptualised as possible and as providing a source of subjectivity and national dignity. 
The focus of this article is therefore on the relationship between Finnish nationalism and ideas of 'marginality' through Finnish history. Being marginal is usually understood in one of two connected ways. On the one hand, it is equated with being either on, near, at or beyond the edge of the core spaces of political life. On the other hand, it is understood as entailing limited power and subjectivity. In this article, however, we contend, first, that marginality is not only about one's 'position' in relation to different power centres, but is also about 'identity'. Second, we highlight that narrating identity in terms of marginality can also be a rhetorical strategy of empowerment, though this has taken significantly different forms throughout Finnish history. In short, therefore, this article demonstrates how, since the nineteenth century, differing narratives of marginality have played important roles in Finnish national identity construction. Whilst marginality has sometimes been seen as something to be escaped in favour of centrality, sometimes it has been viewed more positively in terms of 'splendid isolation', or as expanding the idea of the West and Europe. The principal claim we make, however, is that what marginality is understood to relate to is changing. Traditionally marginality in Finland has been perceived either culturally (in terms of youthfulness) or geopolitically, with marginality concerned with Finland's position in the European balance of power and its relationship to and between the great powers. Today, however, marginality is being detached from conceptions of geopolitics and culture, and in Finland is increasingly narrated in terms of globalisation, with marginality increasingly conceptualised as a temporal/teleological issue, rather than a geopolitical or cultural one. 
A word of caution regarding the claims of this article is, however, necessary. Whilst we contend our focus on marginality and the particular reading of history we draw from this is important, we are not attempting to provide a new hegemonic reading of Finnish history to replace that currently in vogue through East-West conceptualisations of Finnish identity and history. Rather the aim is an emancipatory one, to show on the one hand that other readings are also possible, and on the other hand to add complexity to current debates by illustrating that to a considerable degree various historically specific narratives locating Finland at different points along the East-West continuum have also been heavily informed by (and sometimes even premised on) narratives of marginality. What we do suggest, however, is that in the current situation analysts who continue to locate Finland solely in East-West terms are missing the fact that discourses related to marginality are becoming ever more important and precisely at a time when East-West frames make less sense.

This general absence of any sustained reflection on the role of ideas of marginality in the construction of Finnish identity is notable for at least two reasons. First, it is notable because outsiders have frequently characterised Finland as a marginal space par excellence. At different times Finland has been depicted as a borderland or frontier, a somewhat messy place existing on the edge of Europe and between the great powers. However, Finland's marginality has also been depicted in terms of its 'Northernness' and cold climate, whilst the Finns' presumed racial difference from the Caucasian 'norm' has 
encouraged racial and ethnographic expeditions and contributed to the Finns' 'exoticisation' (and subordination) in the discourses of outsiders. ${ }^{1}$

More significantly, however, this absence is notable because arguably notions of marginality have been imbued in narratives of Finnish nationalism from the beginning. To some extent this has been recognised in the broader literature of nationalism studies where Finnish nationalism is variously categorised as an example of eastern/ethnic nationalism (Roshwald 2001, 5), separatist nationalism (Breuilly 1985), peripheral nationalism (Hechter 2000, 15-17) or, according to Hroch’s (1985) definition, might be seen as representing the movement of a 'non-dominant ethnic group'. Whilst such categorisations are often too simplified and fixed (e.g., as Roshwald (2001, 221) notes, after the First World War the 'ethnic' national movements of Eastern Europe also developed notable 'civic'/western aspects, whilst Finland is also an excellent example of such an ethnic/civic mix) what these various categorisations do capture is the extent to which the Finnish national discourse (and that of other national movements) has from its beginning conceptualised the Finns as a nation emerging from the periphery, as a nation subordinate, subjugated and lacking power, and that to some degree has always had to fight or petition to be heard or recognised as an equal member of the family of nations. Importantly, though, although such categorisations have implicitly recognised the marginality at the heart of the Finnish national movement there has not been any further serious consideration of what influence such marginal positions may entail for the

\footnotetext{
${ }^{1}$ E.g. see the travelogue of Wendy Hall (1953). The Finns' borderland location in the discourses of outsiders can also be seen in Cold War references that often depicted Finland as 'Scandinavia with a difference' (e.g. Connery 1966: 445).
} 
development of such national movements, or more particularly what kinds of discursive practices such marginality may produce.

Our contention is that the need to convince and assure oneself of one's right to exist as a nation and a state is central to all the above mentioned typologies of nationalism. Peripheral nationalism, for example, represents the challenge of a (territorial) margin to a political centre which at a certain point becomes transformed into an open demand for separation. Similarly, Hroch's focus on the 'non-dominant ethnic group' expresses another dimension of the need to convince onself of and assert a nation's self-esteem. In this case the national movement is presented as representing a majority population that has so far lacked socio-political or cultural power, which instead is held by a minority elite part of the population. In the Finnish case this refers to the dominance of Swedish speakers such that Swedish culture and language were comprehended exclusively as representing socio-political power, whilst Finnish was regarded as a peasant-language. Convincing and persuading Finnish speakers of their right to nationhood and assuring them of their capacity to be a true nation therefore became central to national rhetoric. To reiterate, therefore, the point is that Finland is a case where the national movement has, from its origins, been related to questions of exclusion and subordination, of fighting from the margins for a right of existence and national subjectivity. Even if the times of internal struggle have now passed, this concern with gaining recognition and position has remained central in Finland's external relations where a concern with being small, peripheral and marginal has always underlain broader narratives about Finland's place in Europe and its position along the East-West continuum. 
This notion that the search for self esteem, subjectivity and acceptance has particular resonance for national movements that have been imbued with notions of marginality from their beginning also resonates with Greenfeld's $(1995,491)$ argument that "National identity is, fundamentally, a matter of dignity”. For Greenfeld nationalism is frequently driven by the vanity of the community which is always trying to legitimise its position, protect what has been achieved, or trying to move towards a new enhanced position. This search for national dignity is arguably more prescient for smaller and 'younger' nations with a history of emerging from subordination, like the Finns, than for larger and more established nations with histories more of domination, like the English, who to some degree can take their existence, recognition and national dignity more for granted. From our perspective this raises the question of whether national dignity can ever be achieved through a positively narrated understanding and framework of marginality, or whether frames of marginality will rather promote actions to escape them. Ultimately we would argue that narratives of subordination and exclusion are unlikely to provide for national dignity if accepted unchallenged. Marginality cannot in national discourse just be recognised and accepted as a permanent lack of power, but rather needs to be resolved with a view that national dignity can be achieved. However, whether national dignity requires escaping marginality, or whether it can be achieved through embracing it is something we explore below.

A few more words about marginality are therefore in order. In traditional modernist discourses margins and peripheries are usually taken as given, being understood as 
basically fixed entities largely subordinated to more powerful centres, or seen as being somehow self-defined by their backwardness or exclusion from the cultural core. However, margins are not objective facts but social constructions. As indicated above, in the discourses of outsiders, the power of naming and signifying is central to the construction and creation of margins (whilst the naming of the marginal is also central to the construction of the core) (see Shields 1991: 5). Furthermore, whilst the power to ascribe is usually seen to rest with the core, with the core often seen as imposing its definitions on others, this is not always the case. Sometimes entities may freely ascribe an identity of marginality to themselves. At other times, however, they may actively seek to frame the labels applied to them by others in new ways. Thus, instead of seeing marginality as a bind or a negative label depriving them of subjectivity and power, marginality may also be re-conceptualised as a resource and site of action (see Browning and Joenniemi 2004). Similarly, it is also not unusual for 'margins' to define themselves as places of innovation (Ardener 1987: 45-6), or for outsiders to view them as sites of experimentation. $^{2}$

In this respect, and to some extent ignoring the discourses of outsiders, our focus is on how dominant narratives of Finnish national identity have related the nation to ideas of marginality and how in telling marginality in different ways at different times different orientations and ways of relating to world politics have become meaningful. Ultimately, this relies on a 'performative' understanding of the nature of language in that, following Butler (1997, 17-18), we argue that language is not only constitutive of the world (as

\footnotetext{
${ }^{2}$ This has been the case for northern Europe in the post-Cold War period, which the EU, US and Russia have spoken of in terms of being a laboratory for experimenting with new forms of governance and building new relationships (see Browning 2003).
} 
constructivists argue) but also that our representations of identity promote certain kinds of conduct rather than others. Or put otherwise, different readings of marginality, or relating Finland to marginality in different ways (e.g., whether it is to be embraced or escaped), will have a fundamental impact on the nation's vision of itself, of where it is going and which orientations it is likely to consider in its national foreign policy (also see Ringmar 1996).

More particularly, to capture this narrative framework we introduce the notion of 'mindscapes of marginality' to refer to how particular discourses of marginality within national identity narratives are not just descriptive of the current position, but also always prescriptive of how things ought to be. The notion of a 'mindscape of marginality' also highlights that all narratives exist in a wider discursive field constituted by other narratives. In the Finnish case, for example, narratives locating Finland somewhere along the continuum between East and West have been particularly important, though other salient narratives have, for example, focused on Finland as a small state or its relations to Sweden and Swedishness. Similarly, the notion of mindscape also helps illustrate that identity markers (such as of marginality) are always embedded in a web of other concepts (Wæver 2002: 31; Shields 1991: 22). Thus, in the Finnish case marginality often needs to be understood in regard to other concepts such as: North, East, West, Baltic, Europe, civilisation, smallness, borderland, frontier etc... Methodologically this is important since this web of concepts means it is possible to identify a marginality narrative even if the concept itself is not being used in a particular period or instance, but instead can be inferred from the way other related concepts are being deployed. 
In the following, therefore, we aim to map the mindscape of marginality in Finnish identity narratives, with the notion of the mindscape pointing to the interconnectedness of different concepts and narratives, whilst the concept also conjures to mind a mental geography and spatiality. As Liulevicius $(2000,151)$ indicates, once a mindscape has been constructed it provides a mental map, a way of looking at things and one's environment, whilst it also becomes prescriptive of how to move through the mindscape. A mindscape points to what is to be taken as 'normal' and 'abnormal' in a spatial and temporal sense and is thus a guide to the future that frames how to read the current situation and act within it, as well as envisioning the order as it 'ought' to be (Eglitis 2004, 8-10).

\section{From Cultural to Geopolitical Marginality: The Imperial, Inter-War and Cold War Periods}

As noted, it has become popular to argue that the key dynamic in Finnish national identity debates has been one of quite where Finland should locate itself along a spectrum between East and West. Our contention is that whilst this captures much of current debates it has also meant other important dimensions have been neglected. In particular, in our view the East-West frame has also been fundamentally about issues of how Finland relates itself to marginality, and to some extent a mindscape of marginality has underpinned much of the East-West debates of the post-Cold War period. 
In the following, therefore, we provide a revisionist interpretation of identity politics in Finland, one that emphasises mindscapes of marginality over other issues. Because of space our ability to comprehensively demonstrate the case is limited. Consequently, although we provide an overview of marginality narratives from the 1800s onwards, the major focus is on the post-Cold War period where we argue a rather intriguing shift in the foundations of the mindscape of marginality can be identified.

\section{Imperial Margin}

Prior to gaining independence in 1917 it is important to realise that Finnish nationalist discourse adopted a generally positive attitude towards notions of marginality such that emphasising marginality even became constituted as central to the achievement of national dignity, subjectivity and even national existence. Before the First World War the spheres of imagining marginality were primarily cultural and racial, not geopolitical, and were also initially directed in terms of overcoming the dominance of Swedish speakers and Swedish culture in Finland. Central elements to the national movement were therefore such things as the promotion of a Finnish literary heritage and culture and the Fennicisation of the bureaucracy and universities. Drawing on Herderian ideas it was felt that nationhood required inventing a national culture that would pave the way to the future. Folk poems and ethnography became the foundations of developing this national consciousness and building a distinctive Kulturnation (see Wilson 1976). In particular, this contributed to the idealization of the common folk and their harsh life at the margins of subsistence, with the poor and simple being associated with purity and authenticity, 
and with this turning marginality into a virtue. A myth of a stubborn nation never giving in even in the face of great difficulties was constructed (Klinge 1993: 232-3) and became central themes employed by core nationalist writers like Aleksis Kivi (1991/1870) and Juhani Aho (1995). As Smith (2003, 27-40) argues, 'cults of authenticity' like this often constitute the centre of nationalist belief-systems and point to what is considered true and genuine in a society at a particular time. Notably, cults of authenticity often refer to something simple, rude and unaffected or even primitive that is close to the common people. However, in the Finnish case this search for authenticity also has certain unique features, not least through the emphasis on poverty and the harsh climate as sources of the Finnish soul.

The embracing of marginality was also evident in the Finns' attitudes towards the racial theories of the day that tended to categorise the Finnic peoples as Mongols and thus something non-European, uncivilized and even half-witted (see Kemiläinen 1998). Whilst the Finns fought against the negative characterisations of these theories, racial marginality was also embraced since it provided another pillar for differentiating the Finns from their neighbours (particularly the Swedes) and for gaining acceptance as a distinct 'nation'. Indeed, 'racial purity' was also seen as central to the success of Finnish athletes at the Olympics starting from the Stockholm games of 1912. This success was not seen as the result of better training, but as a racial issue. The Finns, it was asserted, had not been degenerated by civilization as 'old' Europeans had been, but retained their vitality (Lehti 2000). 
The emphasis on cultural and racial elements was also evident in that the Finns overwhelmingly imagined their future within the Russian empire, rather than as an independent nation-state. Nonetheless, after being annexed from Sweden in 1809 Finland was granted a special administrative system that left the Finns with their own senate and a unique institutional mechanism enabling the presentation of Finnish affairs directly to the Tsar. The Grand Duchy also had its own legal system and bureaucracy and by the late nineteenth century even its own currency and customs border with the Empire. Administrative developments after 1809 therefore brought Finland close to the imperial centre, whilst simultaneously guaranteeing its uniqueness. In the nineteenth century political struggle with regard to Russia thus concentrated mainly on preserving and developing this system, whilst warding off deeper integration in the Empire. At the same time, key figures in the national movement like Snellman and Yrjö-Koskinen made clear that as a 'small' nation national dignity would be best achieved through adapting to Imperial preferences and focusing on the cultural sphere, rather than through political struggle for independence, which to them seemed highly unrealistic. Following Hegelian logic the Finns were depicted as an emerging nation, and the creation of the Grand Duchy of Finland following Finland's annexation from Sweden by Russia in 1809 was seen as a reflection of the Finns' development towards adulthood (Koskinen 1869).

However, the institution of unification policies, known also as russification, throughout the Empire at the end of the nineteenth century, which aimed at harmonising the Empire's administrative practices and homogenising the Imperial space, and which therefore challenged the Finns' emphasis on their marginal and distinct position within 
the Empire, resulted in confrontation with the Imperial capital. Finnish reactions took three forms. At the extreme there was a small level of support for an 'activist' resistance against the Tsar, with the Activists' ultimate aim being separation and independence. The major political division, however, was between the 'Constitutionalists', who adopted a policy of passive resistance and who asserted Finland's sovereignty was enshrined in legal agreements, and the more conservative 'Old Finns' who adopted a submissive policy. In their view the best option for small and marginal entities like Finland was simply to ride out the storm, demonstrate continued loyalty to the Emperor and wait for better times (Huxley 1990). Importantly, though, membership of the Empire still dominated visions of the future (even for the Constitutionalists) and separation was an alternative only conceivable to a small minority, at least until the final chaotic years of World War I.

Aside from escaping from subjugation under Swedish cultural and linguistic dominance and locating the nation on the fringes of the Russian Empire, frames of marginality were also central in how the Finns positioned themselves in regard to western civilisation. Accepting of their position in the Empire major forums for expressing national dignity became cultural and sporting occasions such as World Exhibitions (Smeds 1996) and sporting events like the Olympic Games (Paasivirta 1963), as opposed to political venues. In these contexts a positive emphasis on marginality as a way to emphasise Finnish uniqueness, subjectivity and national dignity took several forms. On the one hand, it was expressed in terms of an emphasis on naturalistic notions of the Finns as a nation emerging from the wilderness and even in terms of a certain orientalisation of Finnish 
culture. This was evident, for example, in the construction of the Finnish pavilion for the Paris Exhibition of 1900. As Griffiths (1993: 93) describes it:

The Finnish pavilion was made of huge blocks of stone, castellated windows at ground level and a steeply pitched roof. The roof line was broken by a series of short flag poles and the whole surmounted by a huge tower which had more than faint suggestions of the Middle East, blended with art nouveau touches. The door to the pavilion was guarded not by classic figures of antiquity but by the bears and squirrels that expressed Finnishness through the country's fauna.

Rather than playing down marginality and copying the mainstream styles of the core, Finland's marginality and difference was notably exaggerated in this context. Indeed, the landscape of forests and lakes became an embodiment of the nation, and thus 'the wilderness', but also the cold climate and Finland's northernness, was similarly used to assert the uniqueness of Finnishness in relation to nations with a long history of ‘civilization’ (Mikkeli 2000; Valenius 2004, 90-98).

On the other hand, marginality was also expressed positively in terms of vitality and youthfulness. Being 'young' in comparison to old established European nations became a dominating notion in the construction of Finnish national identity. Thus, although the Finns were often presented (by themselves as well as by others) as marginal, they also introduced themselves as 'nations of the dawn' to whom the next century would belong. This metaphor was clearly seen, for example, in emerging feelings of pan-Finnishness 
that called for establishing the unity of all Finno-Ugrians under Finnish leadership and declared how the next century would belong to them (Wilson 1976: 138-9).

In sum, the mindscape of marginality in the pre-First World War era was constructed through a series of dichotomies. These included those of: youth versus maturity, future versus past, vitality versus decadence, nature and wilderness versus culture and civilisation. Finland according to the Finns belonged to the first of each category. Finnishness was thus constituted through marginality, with such a position being understood as necessary to guarantee the nation's uniqueness and for guiding the Finns into the future. Rhetorically, therefore, marginality was thus embraced, with Finland seen as emerging from the margins (wilderness) to claim its place in the family of nations. The margin here, understood in cultural and naturalistic terms, was a refuge and shaper of the Finnish national character.

\section{Vanguard state}

In the interwar period a mindscape of marginality remained important in framing Finnish orientations and self-understandings, however, the mindscape shifted from a cultural frame of reference to an increasingly geopolitical one, and where 'size' also became an

ever more salient consideration. At the same time this reframing of the marginality mindscape also became intertwined with discourses related to Finland's position in EastWest relations. 
The impact of World War I was central to the shift towards geopolitical thinking, and also prompted new ways of thinking about national sovereignty that now prioritised independence over autonomy within Russia, with 1917 marking not just the end of imperial Russia, but also of its dominance for framing the future. 'Smallness' was the overwhelming feeling in the midst of the ongoing political chaos, with smallness overwhelmingly understood in terms of vulnerability and precariousness. Such feelings were not surprising given that this was a period in European politics where the future was seen to lie with big states and when concepts like that of Lebensraum were being used (Cohen 1964, 41). Interestingly, in Finland this saw the popularisation of ideas of a forthcoming Greater Finland and this remained a dream of the right through to the end of the Second World War. The result, however, was that in interwar Finland the notion of smallness and certain defiance in the face of this were interestingly mixed.

After World War I 'Baltic' became a central label for locating a number of the Russian successor states within Europe and the idea of a Baltic League gained support, especially in Estonia and Latvia, but also in Finland, as a defence against the 'problem' of smallness. Interestingly, in Finland terms like the ‘border states' or 'diagonal zone' were used to describe the belt of new states on the Russian border - including Finland - with this position at times being given a positive value (Lehti 1999, 219-227). Thus, as V.M.J. Viljanen (1920, 31-3) put it:

They [the border-states] belong to the same central diagonal zone in Europe as we do and they possess some of the richest lands in Europe, eminently suitable for 
economic development. On account of their key position and a population that comprises altogether about 85 million souls, they will, sooner or later, come to have an important political and economic significance in Europe. ${ }^{3}$

Such concepts located Finland as a country on the edge, at the frontier, or in the margins between core spaces of European politics. Echoes of earlier bluster that bragged of raising the margin to become a new centre were also clearly written into this vision of 'new Europe'.

In particular, the eastern border came to dominate Finnish national imagination and was depicted not only as a state border, but as a border separating different cultures and political systems and that even stood as the dividing line between Europe and Asia. In this respect, Finland was described as a 'vanguard state' and seen as an outpost of the West standing alone against the East (Immonen 1987) and where the margin was understood, at one and the same time, as a site of danger - the fear being that Finland would be submerged "in the great ocean of Slavic nations" (Hannula 1939: 20) - and as constitutive of a national purpose and mission for the newly independent nation: a mission to stand guard against the East. Such imagery was best captured in a popular poem by Unto Kailas called, ‘On the Boundary’.

The border opens like a crack.

In front of us is Asia, the East.

\footnotetext{
${ }^{3}$ Importantly, though, not all in Finland shared this sense of solidarity with the border states and rather chose to exclude Finland from this group in favour of emphasising connections to Scandinavia (Lehti 1999, 227-238).
} 


\section{Behind us is the West and Europe;}

I will guard it as a sentry...

(quoted in Paasi 1996: 171)

Thus, whilst East-West narratives were clearly central in debates about Finnish identity, the notion of marginality and its implications for Finland also played a key constitutive role in just how this East-West frame played out. In other words, the nature of Finland's Westernness was fundamentally shaped by the mindscape of marginality operating at the time.

New heroic historical narratives were introduced to strengthen the national mission and, as indicated, the Finns were presented as a kind of Soldier Nation with a great heritage of military exploits to be found since pre-historical time (Meinander 1999: 122-5). Capturing the era's overarching mentality, the marginal activist resistance movement of the early $20^{\text {th }}$ century was now praised in popular historical movies as an example of national heroism and resistance (Laine 1999). However, imagining Finnish heroic adventures was not limited to the past but was extended into the future too. Thus, in Finnish novels Petrograd was frequently conquered and ravaged because it was built on Finnish soil (Peuranen 1995, 7). Finland, therefore, was depicted as western in contrast to an often lustful East. The division between East and West, Russia and Finland was also openly racist. "Russophobic" narratives depicting Russians as evil, treacherous and sexually perverse dominated, while the Finns instead were seen to represent purity, honesty and loyalty (Karemaa 1998; Laine 1999, 249-304). As noted, marginality, here, 
was presented as a matter of honour in standing alone against the East, against communism and Asia. In this respect, Finland's position on the margin, and the mission this was seen to give Finland to defend the West against the Bolshevik Slavic East, was also ironically a mission that utilised marginality to grant Finland a central role in the East-West struggle. Notably such representations were to come to dramatic fruition in the Finnish-Soviet Winter War of 1939-1940, in which small Finland was popularly characterised in Finland (and abroad) in terms of David standing up to the evil Soviet Goliath.

In all, following World War I marginality was transformed from a preoccupation with cultural and racial backwardness and distinctiveness to concerns with Finland's geopolitical location and size as a newly independent small state in a Europe largely defined by the great powers. Demonising Russia, and the feeling of living on the edge of the Western world as a vanguard state, were dominating narratives. Finns were depicted as brace northern barbarians who would get by with more civilized European nations on their own terms. Marginality and peripherality here were hidden behind heroic narratives that looked to the past as a way to project the national mission into the future and that also proclaimed the Finns as playing a role central to the defence of Western civilisation. The narrative still had utopian elements, in particular in the 1920s, but generally the tone was rather defensive - to concentrate on securing what had been achieved. Trusting in one’s own resources was a key element of this mental map of marginality.

Grey zone 
Whereas inter-war national narratives had constructed Finland's marginality in terms of being the border guard of the West - thereby emphasising marginality to grant Finland a central role in the defence of the West - throughout the Cold War dominant narratives emphasised Finland's peripherality in order to locate the country outside of the East-West conflict. However, despite the different reading marginality continued to be viewed positively and when linked to concepts such as 'Nordic' it represented the possibility to escape from the Cold War conflict altogether. Moreover, this position on the edge, in what was sometimes called Europe's ‘quiet corner', also became a position from which Finland might act and carve out a niche for itself in the international politics of the Cold War.

Central to this shift was a reappraisal led by President Paasikivi (1946-56) following the end of World War II that sought to account for why inter-war foreign policy had failed to prevent the outbreak of war with the Soviet Union in 1939. Paasikivi argued that Russophobic characterisations of the Soviet Union/Russia as the Finns' hereditary enemy represented a misreading of Soviet/Russian intentions. Rather than being an inherently aggressive and evil hegemon, Paasikivi (1956: 35-6) argued Moscow’s territorial interests in Finland at the end of the 1930s were not ideological and expansionist, but legitimate, strategic and defensive in nature. Paasikivi demanded a thorough expunging of negative attitudes, protestations and symbols of the Eastern neighbour. This became manifest, for example, in the 'cleansing' of negative references to the Soviet Union from school textbooks and the removal of books containing 'hostile' representations of the Soviet Union from public libraries (Salokangas 1996: 117; Hadjú and Paasi 1995: 43). 
Similarly, revisionist histories provided a more positive take on Finnish-Russian relations and in doing so provided a roadmap for future positive relations. Thus, inter-war characterisations that presented Finnish-Russian relations as dogged by innumerable wars and open hostility, gave way to new histories emphasising a different historical continuity of peaceful coexistence (Korhonen 1969: 33). A certain return to the late $19^{\text {th }}$ century reading of Finnish-Russian relations was noticeable that emphasised the importance of the separation from Sweden as the beginning of a Finnish state guaranteed by the Tsar. However, it also clearly interpreted Finnish-Russian relations as those between sovereign equals, even if sharing the same ruler. This reading of the Finns' unique position in Russia appealed to post-Cold War readings of Finnish-Soviet relations of being close friends, but simultaneously separate entities. Further, the war and the defeat against the Soviet Union also called for acceptable interpretation to preserve a sense of national dignity. A myth of victorious defeat in which Finland's sovereignty was won was thus created, ${ }^{4}$ and which was linked with the idea of Finland as a piece of driftwood caught in the maelstrom of European great power politics and that therefore had little choice in its actions (Jokisipilä 2005). This determinism was premised on a very negative reading of Finland as small state in a realpolitik world and where smallness was equated with a distinct lack of subjectivity. This was then taken to characterize future options available

\footnotetext{
${ }^{4}$ Particularly notable was the idea that instead of losing the war Finland had come a creditable second, for the reason that ultimately independence had been preserved, whilst other than London and Moscow, Helsinki was the only European capital city (of those states at war) that had not been occupied. This notion of coming second can, for example, be seen in Väinö Linna's novel Tuntematon sotilas (The Unknown Soldier - 1954). This novel was not only a best seller that was adapted to film, but was also a key text in explaining the nature of the war to the Finns, as well as in encouraging reconciliation between the left and right of society.
} 
to Finland and was also used to elicit sympathy for its position and policy on the international stage. As Paasikivi put it:

The voice of small states isn't heard in the present concert of big powers. Only big powers play a decisive role at the world stage. The tasks and impact of big powers is due to the circumstances different than those of small states who in realizing the proportions must understand the necessity of reservedness (quoted in Tiilikainen 2006: 75).

As a small state subject to the whim of others' actions the best Finland could hope for was to keep its head down and be left alone. Indeed, being small, here, was seen as a question of survival, of the life and death of the nation. Ultimately, this securitisation of Finland's size was to have negative effects for Finnish democracy as foreign policy issues became the preserve of the President and put beyond public debate, whilst under president Kekkonen (1956-81) the domain of foreign policy was also extended such that the people were seen to have responsibility not to challenge the official line or more particularly to put Finnish-Soviet relations in jeopardy through 'irresponsible' critiques of the Eastern neighbour (Arter 1998).

In this context, 'neutrality’ constituted a core term that was seen as essential for securing state sovereignty and to which all other issues were subordinate (Alasuutari and Ruuska 1999: 89). Therefore, 'neutrality' also constituted a major rhetorical turn to achieve national dignity as a small power acknowledging the dominance of big powers. Finland's 
neutrality policy also resonated with the Snellmanian view of the nineteenth century, and explicitly drew on that Fennoman heritage, that Finland should be prepared to adapt itself to Soviet preferences and even anticipate their wishes. More broadly, though, Finland's neutrality policy was understood as a way to isolate the country from the Cold War, to keep out of the international limelight and to send a message to the Soviet Union that they had no reason to worry about Finland. At the same time, emphasising Finland's smallness became a way to gain understanding, to locate Finland in the margins of the Cold War by presenting Finland as harmless, and thereby to keep the great powers at a distance.

This embracing of a position of marginality in relation to the Cold War conflict was also promoted by emphasising the nation's Nordic identity throughout the period. Emphasising Nordicity achieved at least three aims. First, presenting Finland as a Nordic country (rather than a Western outpost as in the interwar period) was a way to express “Finland's psychological bonds with the Western world" without unduly provoking the Soviet Union (Nousiainen 1963: 189). Second, a Nordic orientation discursively differentiated Finland from the precarious region of Eastern Europe and the Baltic republics, and placed Finland in the category of the stable and accepted Nordic group of sovereign states (Kettunen 2001: 234; Wæver 1992: 79). Third, this self-proclaimed position on the northern/Nordic margins also became understood as a position from which to speak and gain subjectivity - and thereby to even begin to escape passivity in international affairs for a more activist stance. In this respect, the idea that the Nordic countries could be peace builders and mediators in East-West issues (but also between 
the global north and south) was widely promoted, with President Kekkonen even proclaiming to the UN in 1961 that Finland saw itself as a physician trying to cure the problems of world politics (Kekkonen 1970: 94).

The notion of being Nordic also became associated with the evolving Nordic way of life built around the welfare state and concepts of egalitarianism and progressiveness. From the 1960s onwards Finland experienced a remarkably swift process of modernisation and urbanisation, such that by the 1980s it was common for Finnish school children to hear that being born in Finland was like winning the lottery of life. Such rapid developments went some way to usurping images of Finland as a poor and backward country, even if popular culture continued to romanticise the agrarian way of life. The state, however, became depicted as at the forefront of ultra-modern states. ${ }^{5}$ In the ideological conflict of the Cold War the prosperous Nordic welfare states with their strong emphasis on social justice were seen to have found a middle way through the ideological divide (Hanhimäki 1997: xii). In turn this perception became a further support for bridge building and activism in foreign policy, as well as for providing grounds for a narrative supporting national dignity.

In the Cold War period, therefore, the identification of Finland as a state in the margins was rather overt. When linked to concepts such as the Nordic being marginal was seen to represent the possibility to escape from the Cold War conflict. At the same time, however, being in the margin, being somehow 'between' and being small, also became

\footnotetext{
${ }^{5}$ On Finnish modernisation see Meinander (1999: 358-62); Alasuutari and Ruuska (1999: 85). About popular culture see Salmi and Kallioniemi (2000).
} 
understood as resources providing grounds for Finland to gain subjectivity and an international role premised on bridge building. Thus, the discourse on 'neutrality' became the main source of national dignity and the status of which is was therefore necessary to secure.

\section{From Geopolitics to Globalisation: The Post-Cold-War Era}

In the post-Cold War period marginality has been both embraced and seen as something perilous, whilst marginality in the 1990s also remained explicitly tied to a broader EastWest framework. However, if the 'westernising' geopolitical narrative of marginality dominated in the 1990s it seems a change has begun to occur in the early $21^{\text {st }}$ century. Indeed, it seems the East-West framework has lost its omnipresent position and has been replaced by globalisation and the power of markets as key markers in the national discourse considered central to achieving national dignity in the future. In turn this has transformed marginality into something non-territorial and rather focused on questions of ability.

Geopolitics in the 1990s

The end of the Cold War became a catalyst for strong 'Westernising' narratives in Finland, whilst the experience of being located on the civilisational border between Byzantine and Roman Europes also became surprisingly conscious (Ruokanen and Nurmio 1995: 70; see also ‘A Northern Dimension’ video). On the one hand, dominant 
narratives in the 1990s depicted marginality negatively, as something to be rejected and escaped. Here Finland was to be re-located to the Western side of the East-West boundary (as in inter-war narratives) rather than being a border zone, as in the Cold War. On the other hand, however, marginality has also been depicted as a resource that can be utilised precisely to relocate Finland at the geopolitical centre. In other words, playing on marginality was central in rejecting it in the 1990s.

The Soviet Union's demise was experienced with some confusion in Finland, since it also meant losing a safe and stable position in the margins. A simultaneous economic depression strengthened feelings that the country was a piece of driftwood in the flows of history. Whereas previously the Finns had escaped into a shell of 'neutrality', imagining Finland as a safe-haven in the great power conflict, of limited interest to others and unwilling to intervene in others' business, now a new 'return to Europe' narrative located Finland differently and forced it to open up towards Europe.

This 'Westernising' narrative argued that Finland should return home to its Western heritage, which it had been denied throughout the Cold War (Browning 2002). This has entailed a fundamental revision that reads Finland's Cold War position between East and West as artificial and as the forced estrangement from its natural Western location. Historiographical and rhetorical naturalisations of Finland's Westernness and Europeanness therefore became common in the 1990s, with the country's history frequently presented as a journey from the periphery of Europe to its centre (Lehtonen 1999: 5). Racial/linguistic theories also returned to prove the Finns' Western origins 
(Wiik 2002: 341-342), rather than emphasising Eastern influences and origins as in the Cold War. In this respect, the revisionist interpretation of history has asserted that neutrality and Finland's Cold War position 'between East and West' were not questions of Finnish identity, but of Finnish pragmatism, with this being as far West as the Finns could get.

In this context, marginality has often been read negatively in regard to the Cold War, being understood as the absence or forced denial of the 'real' 'Western' self. The West and Europe were presented as 'normal' and the 'return to Europe' a 'return to normality' from the abnormality of the past. This mindscape located Finland as no longer stuck on the periphery, but as moving from the periphery and the East towards the European and Western centre. Whereas previously emphasising a position on the margins was seen to emphasise one's difference, thereby contributing to national identity construction and state sovereignty, the Westernising discourses saw difference from the Western core as problematic and as something to be overcome in favour of conformity and standardisation. These discourses, therefore, promoted moves towards EU membership in Finland (1995).

Past experiences remained central to structuring this narrative and for providing a guide for the future. The experience of being a victim of Soviet aggression in World War II, and largely without foreign aid, was surprisingly strong. The danger of again being left outside in the 'grey zone' was a powerful idea in Finland. During the 1994 Finnish referendum campaign on EU membership Simopekka Nortamo, the editor of Helsingin 
Sanomat, Finland's dominant daily newspaper, described staying outside the EU as leaving Finland stuck "between chaos and stable conditions, between poverty and wealth, between democratic and undemocratic regimes", and proclaimed a no vote would enhance the perception that Finland is an 'Eastern country’ (cited in Kuisma 2003: 20910). According to Helsingin Sanomat Finland was previously a 'retarded' peripheral and inward looking country (Alasuutari and Ruuska 1999: 102). Thus, what was previously seen as splendid isolation and a source of pride of being ahead of 'old' Europeans was now regarded as something shameful and marginal and which through 'Westernization' could be escaped.

Indeed, in this respect membership of the 'Western’ EU was not enough. Instead, central to dominant discourses in the 1990s was the view that Finland not only needs to be a member, but needs to be a 'core' member at the forefront of all integration efforts. A key voice here was Prime Minister Paavo Lipponen who has held a firm belief that Finland needs to be at the EU core in all areas in order to avoid the big states making decisions over the Finns' heads. Lipponen's view is interesting in that it indicates a continued concern with Finland being a small and marginal state, where smallness and marginality can be overcome by becoming fully integrated in (indeed, at the forefront of) the European project. $^{6}$ Thus, whereas previously integration was comprehended as threatening, it was now re-conceptualised as necessary for national survival - although in this context the discourse has been less about state security, with sovereignty increasingly

\footnotetext{
${ }^{6}$ Notably, Erkki Tuomioja, Finland's Foreign Minister and longer term rival of Lipponen in the SDP, has criticized people like Lipponen precisely for being stuck in a 'Tilsit syndrome', with this referring to the agreement between Napoleon and the Tsar to divide Europe into different spheres.
} 
being seen more in terms of national culture (Joenniemi 2002: Alasuutari and Ruuska 1999: 105).

Finally, the Westernising narratives, and their relationship to marginality, can only be fully understood if put in the context of the Finns' more immediate concerns of how to deal with a weakening, unpredictable Russia. Implicit here has been a negative othering of Russia as a threat to Finland, with the threat presented civilisationally, in terms of the chaos and social degeneration seen to lie across the Eastern border (e.g. Pihjala 1999, Moisio and Harle 2002). Thus, Finland's position as the West's border with Russia became understood as potentially threatening and as a source of vulnerability. Interestingly, though, such discourses of the Russian threat have also been central to an attempt to utilise Finland's position on the edge to enhance its escape from the margin to the core.

Central here has been Finland's Northern Dimension (ND) initiative, a policy proposal launched in 1997 aimed at making EU policies towards the North and North West Russia, in particular, more coherent. In essence the ND's successful marketing rested on convincing core EU members that with Finland's membership of the EU northern problems, and more particularly security concerns regarding Finnish-Russian relations, were also of central importance for the EU as a whole. The initiative has consciously played on ideas of Finland as located in the Northern margins, but in a way that defines the Finns as innovators and pioneers in the new regional cooperation and that enables the Finns to play a constitutive role in Europe-making by making Finland useful for the EU 
as the key manager of the EU-Russian border in the North (Joenniemi 2003: 234-7). However, instead of the existence of a common North, the North is depicted as divided between the wealthy, modern, hi-tech and industrious West encompassing the Nordic and Baltic States, and the backward, undeveloped, primitive spaces in the East. As such the narrative justifies a role for Finland in advising and providing patronage to aid the development of the East (Lehti 2002, 350-353). ${ }^{7}$

In this respect, the ND is an expression of the dominant Westernising discourse. The ND re-inscribes the idea of a civilisational border even in the process of aiming to overcome it. This border is not one of radical othering, but is to be controlled. As such the policy is one that utilises Finland's border position to its advantage by reasserting the importance of Finland to the EU (the centre). In some sense the policy can be seen as one designed to depict Finland as a part of the centre in the North, whilst simultaneously pointing to the significance of the northern margin for Brussels.

\section{From Geopolitics to Economics}

With EU membership, however, asserting one’s Westernness has become less salient. If 'returning to the West' was understood as a 'return to normality', having achieved the goal it has now lost some of its importance, whilst it is no longer clear what constitutes 'normality' and being 'Western' in this context. It has therefore become necessary to be more proactive in defining one's standpoint on the global scene.

\footnotetext{
${ }^{7}$ For such images see the 1999 video made by the Finnish Foreign Ministry on the ND http://virtual.finland.fi/finfo/english/northdim2.html
} 
A repositioning of Finland that draws explicitly on a mindscape of marginality, but this time outside the East-West frame, has therefore become evident and can be highlighted through analysing two recent texts that have been influential in Finnish national debate. The first is the report, Roadmap to Finland's Future Success, released in September 2004 by the influential Finnish Business and Policy Forum (EVA) (Ruokanen 2004). Whereas previously the business elite has played only a limited role in national opinion formation, with this instead being the domain of the foreign policy elite and academics, following the dramatic geopolitical changes of the 1990s and the concomitant economic recession, the EVA report reflects a view that the old order and traditional assumptions for locating the nation no longer hold. The report therefore argues that dramatic changes are needed to save Finland from otherwise imminent degradation. Unlike previously (and not least in Westernising narratives) when 'threats' were seen as located in the past or present (i.e., returning to or escaping the past), in the EVA report threats are now located in the future with the emphasis rather on forgetting the past.

In particular, the Roadmap contends that the fundamental framework for anchoring the nation has changed to become the world of globalized markets, which are seen as dominated by the determinism of market forces. Markets are conceptualised as fluid and therefore there is no fixed position guaranteeing success. Thus, whilst markets cannot be managed, the report argues that the nation needs to successfully adapt to the global competition over markets, an environment in which there is only room for winners and losers. 
The report is interesting not only in what is mentioned and emphasised, but also in what is not. Notably international politics goes unmentioned and is seen as unimportant for Finland's success - only economic development is noticed. The assumption is that international politics cannot drastically influence market forces, which whilst understood as changeable are seemingly following timeless rules. Interestingly, the report also promotes a new attitude towards Russia based on the assumption that Finland's geopolitical neighbourhood is no longer so constraining. In contrast to attempts to differentiate from Russia, Finland, it is argued, should become Russia’s spokesperson in the EU. Interestingly the report argues the Finns have been trapped with recent history and in particular the experiences of World War II. Instead, it emphasises the $19^{\text {th }}$ century Grand Duchy as a time when Finnish-Russian relations were based on mutual understanding. ${ }^{8}$

The report's attitude towards marginality, or more precisely peripherality, is twofold. First, Finland is seen as characterised by its closeness to Russia, coldness and its out-ofthe-way location, but is simultaneously seen as a safe developed country. Despite the political rhetoric of the 1990s, it is now argued Finland no longer needs to 'join the core', but should try to become one of a select group of 'vanguard states' (but not in the terms of the interwar period) in the EU in all areas of development - i.e., a state that is out front and a leader, as opposed to finding safety in being just one amongst many (see also

\footnotetext{
${ }^{8}$ Interestingly, an alternative and more positive interpretation of Finnish-Russian history has also been introduced, with the Finns' membership of the Russian Empire now examined more openly than before. This has included St. Petersburg being depicted as an elemental city in Finnish history through which the Finns became part of Europe's belle époque (Klinge 1997; Engman 2002; Lehti 2001). This narrative preserves the notion of Finland as a bridging space, whilst also problematising straightforward exclusions of Russia as the 'other' in the more dominant Westernising narratives.
} 
Antola 2004). The alternative and worst scenario for Finland's future is that it fails to adapt to the challenges of globalisation and rather becomes a peripheral and regressive backwater of Europe, a kind of nature reserve focused on environmental issues and ecotourism and with a population of ageing alcoholics. Second, however, marginality is no longer about geography and one's location in relation to external issues, but is comprehended as an internal inability continuously to renew the nation to cope with global markets. To avoid such marginality Finland needs to become a 'global top performer' (Ruokanen 2004: 28). Marginality is thus comprehended as a non-territorial phenomenon that is linked to internal capacity and capability.

Ultimately, the report sees Finland as an individual player in the global competition. However, despite the narrative's rejection of the notion of peripheralisation the narrative can also be read as a return or reinvention of previous traditions of marginality that cherished Finland's separateness and capability to stand alone - in this case in relation to the EU. This can also be seen, for example, in how Jorma Ollila, the CEO of Nokia, has stressed the importance of sisu in carving success out of global competition (Repo and Melander 2005). Sisu is a unique Finnish word referring to personal/national qualities of courage, guts, perseverance and determination and in this case easily connects with the heroic narratives associated with Finland’s lonely fight in the Winter War.

Whilst not everyone agrees with the EVA report's message and different possible future scenarios for Finland, based as they are on neo-liberal economic theories, the report nonetheless captures a growing tendency in society to look at Finland from a global 
perspective, prioritising economics over politics and thus securitising socio-economic issues. ${ }^{9}$ In somewhat different ways, therefore, this can also be seen in the second text, an influential book by Manuel Castells and Pekka Himanen (2004: esp. 127-39), which explores why Finland has been so successful in embracing information technology without forsaking the welfare state.

Whilst Castells and Himanen's approach entails greater concern for social justice than the EVA report, and rejects unfettered neoliberalism, their argument is framed explicitly in terms of coping with globalisation and marginality narratives. In their view a central reason why Finland has successfully embraced globalisation and hi-technology derives from Finland's history as a northern frontier, which they argue has therefore had the effect of making questions of survival particularly important for the Finns. The northern frontier, here, is understood as a cultural frontier, a political frontier, and not least as a climatic frontier. 'Survival' has therefore been a concern at different levels and might be said to have impacted on the psychological consciousness and national character (and culture) of the nation. The focus on survival, they argue, has meant that Finnish identity has been future-oriented, pragmatic, adaptable and embracing of new ideas and technologies (2004: 133). Being on the margins (of life/global politics) is understood as providing Finland with competence and resources that older, larger and more centrally located European countries lack. As they put it:

\footnotetext{
${ }^{9}$ Kuisma (2003: 203-4, 219-24) similarly indicates how globalisation processes have become seen as inevitable (and desirable) amongst the Finnish political elite, with the consequent view being that "In order to survive it is necessary to adjust to the demands of globalisation" (2003: 204). He also notes there are similarities here with the 'driftwood' theory of the Cold War, but this time connected with economic rather than geopolitical imperatives (2003: 223-4). Also see Anttonen (2005: 117-8).
} 
The Finns do not feel that their country has come of age, unlike other European countries with thousands of years of history. The information-society project suits a young country that is still partly in search of an identity. With little history to build on, the Finns are oriented to the future. For Finland, the 'post-survival' culture is something that is being created now; looking forward and not backward (2004: 132).

Again, and with some similarity to the geopolitical Westernising discourses of the 1990s, marginality is presented as a resource to escape marginality. Similarly, there are also close links with nineteenth century narratives that depicted the Finns as a young and virile nation, a nation of the future. However, whereas previous discourses primarily conceptualised marginality in spatial and geographic terms, this discourse on Finland as a youthful innovator rather locates marginality temporally/teleologically. In other words, Castells and Himanen implicitly point to a threefold division between backward societies lagging behind in terms of development, the core developed world able to adapt to technological innovation, if with some difficulty, and vanguard states (whether big or small) who not only embrace technological innovation but are its pioneers. The aim, therefore, is not to get to the core to find safety, but to move beyond the core. The aim is not to locate Finland in the core of Europe, but to conceptualise Finland in global terms with Finland establishing itself as a central hub and nodal point in a globalised world.

As stated, though, whilst this is a discourse about leaving marginality behind once and for all, it remains premised precisely on a history of marginality. Finland can only escape 
marginality and be a world leader because it was marginal, because Finland's marginality put questions of survival at the centre of Finnish national identity and culture and made adaptability, pragmatism and innovativism core Finnish values. At one and the same time then marginality is both rejected and seen as providing the nation with valuable cultural resources.

Despite their differences, therefore, Castells and Himanen agree with the EVA report in that it is not so much the existence of the state but national welfare that is threatened by globalisation. Preserving and increasing competitiveness has thus become viewed as a new vital national interest across much of the political spectrum. This globalised discourse has not broken the dominance of national rhetoric, but has resulted in national sovereignty being interpreted in a new way, and in this process the globalised story has become a new unifying narrative for the nation. Put otherwise, competitiveness is not considered a matter for individual companies, but is perceived (even by business elites such as at EVA) as a question for the whole nation. In this perspective the future is always uncertain and changeable and therefore the key to future success is adaptability and the capability to react even before change has taken place. In this narrative past national experiences have lost some of their meaning in defining contemporary national threats, with the source of national dignity now being seen to lie in Finland's competitiveness and ability to stand in the vanguard among other nations of the neoliberal West. 


\section{Conclusion}

The aim of this article has been to show how mindscapes of marginality have been central to understanding identity debates in Finland, which in turn have played a key role in shaping the broader directions of Finland in the world. In doing so the aim has also been to challenge the current tendency to analyse Finnish identity debates simply through the lens of an East-West framework, in part by showing that this frame only begins to make sense once discursive structures of marginality are also taken into account. Thus, Finland's 'Westernness' or 'betweeness', or policies of being a Western outpost or a neutral bridge-builder, have been provided with a particular flavour by deeper discursive structures of marginality. More particularly we have also argued that the existence of marginality mindscapes as a grounding frame for Finnish national debates ultimately has its origins in the birth of the national project, where 'Finnishness' was always seen as in the process of escaping from subordination and negation and of trying to achieve recognition and a sense of national dignity.

Attempts to assert national dignity in the context of mindscapes of marginality, however, have occurred in two ways. On the one hand, marginality has been embraced, with the nation trying to escape to marginality. Thus, in the nineteenth century and in the Cold War emphasizing marginality became seen as providing a basis for subjectivity and as a move towards a site of security. The margin became conceptualized as a resource from which to take a positive stand, and became understood as something to be treasured and preserved. However, at other times, marginality has been associated with a position of 
insecurity or of a lack of power and visibility. Thus, in the inter-war period and in the 1990s the overwhelming aim was to escape from marginality, to replace marginality with centrality or, as in the current period, to even move beyond the centre to become a world leader, pioneer and innovator. However, even when the goal has been to escape marginality, marginality narratives have remained constitutive of the national discourse. First, this has been because the idea of a margin to be rejected has provided a conceptual direction and sense of movement for the nation in its attempt to attain national dignity. Second, though, often the claim to centrality or of being a vanguard state has paradoxically been supported by attributes derived precisely from a sense of marginality. Thus, in the inter-war period it was precisely Finland's geopolitical location on the Western edge that was seen to provide it with a central role in the fight against the East, whilst in the current period it is the history of cultural, political and climatic marginality that is seen to underlie why Finns are pragmatic and able to grasp the technological mantle. In these instances, marginality (even if it is to be rejected) has been seen to characterize the Finns as young, active and virile, with Finland moving into the limelight by usurping the older, more conservative and lethargic traditional core.

Finally, in telling this story the article has also illustrated that quite what 'margin' has meant in different mindscapes of marginality has varied significantly through time. For example, in the nineteenth century marginality was equated largely with cultural issues, whilst throughout much of the twentieth century it was linked primarily with ideas of geopolitics and spatial location. Today, however, these traditional mindscapes of 
marginality are now being challenged by a new set of narratives that depict marginality more in terms of issues of economics and globalization.

Dominating views on the mindscape of marginality have also contributed to different kinds of political actions in different periods. In the nineteenth century, the mindscape emphasised utilising marginality (northerness, the equation of poverty with purity) and in this process established visionary elements to be achieved in the distant future. Thus, politics towards the political centre in St. Petersburg was flexible and defensive and instead of looking actively for changes and reforms, policy could be characterised merely as determinist. The interwar reading of the mindscape of marginality mixed smallness and defiance and contributed to a belief in the Finns' ability to stand alone against anyone. It also supported a belief in visionary goals like that of Greater Finland. Simultaneously, though, a certain modesty prevented the Finns from engaging in open challenge before it was necessary in 1939. The Cold War era saw a re-conceptualisation of marginality as a virtue and introduced it as a fixed position. Thus, preserving marginality by seeking cover under the shell of 'neutrality' became a dominating principle of foreign policy. In the post-Cold War era, visionary elements returned to the mindscape, receiving their expression in the goal to be one of the core states of the EU. However, in contrast to earlier periods, where change was perceived as a process of decades, now it was imagined in years and as potentially rather swift. Making the issue more complex, however, was that going to the centre was seen to require utilising Finland's position on the civilisational border. The last turn represents a return to more determinist thinking, in which positions at the margin or in the centre are understood as 
questions of internal capacity and which, in this case, are seen to provide Finland with a pragmatic ability to be flexible in foreign policy.

Putting the argument in more general terms we would argue that marginality is a core element of national discourses in certain categories of nationalism and where coping with marginality becomes a central dynamic of national identity building. However, marginality is not a straight-jacket but may be a rather flexible phenomenon that can be transformed from a sign of weakness to a source of authenticity. Thus, even if marginality is always related to others constituted as the centre, and therefore has certain constraining structural elements about it, those understood as marginal can have considerable freedom over how marginality is interpreted and what being marginal is taken to mean and in this respect can be a notable source of subjectivity for nations falling into this category.

\section{$\underline{\text { References }}$}

Aho, J. (1995) 'Pioneers’, in Scandinavian Short Stories (Senate) pp.275-78.

Alasuutari, P. and Ruuska, P. (1999) Post-Patria? Globalisaation kulttuuri Suomessa. Tampere, Vastapaino.

Antola, E. (2004) Suomi EU:n etujoukkoon - Eurooppa-politiikan uudet haasteet. Helsinki, EVA.

Anttonen, P. J. (2005) Tradition through Modernity: Postmodernism and the Nation-State in Folklore Scholarship. Helsinki, Finnish Literature Society.

Ardener, E (1987) 'Remote Areas: Some Theoretical Considerations’, in A. Jackson (ed.), Anthropology at Home (London: Tavistock Publications) pp.38-54.

Arter, D. (1995) 'The EU Referendum in Finland on 16 October 1994: A Vote for the West, not for Maastricht', Journal of Common Market Studies (Vol.33, No.3)

Arter, D. (1998) 'Kekkonen and the 'Dark Age’ of Finlandised Politics?', Irish Studies in International Affairs (Vol.9).

Breuilly, J. (1985): Nationalism and the State. Chicago: University of Chicago Press. 
Browning, C. S. (2002) 'Coming Home or Moving Home? “Westernising” Narratives in Finnish Foreign Policy and the Re-interpretation of Past Identities’, Cooperation and Conflict 37/1, pp.47-72.

Browning, C. S. (2003) ‘Towards a New Agenda? US, Russian and EU Policies in Northern Europe’, in Lars Hedegaard and Bjarne Lindström (eds.) The NEBI Yearbook 2003 - North European and Baltic Sea Integration (Berlin: Springer) pp.273-289.

Browning, C. S. and Joenniemi, P. (2004) 'Contending Discourses of Marginality: The Case of Kaliningrad', Geopolitics 9(3), 699-730.

Butler, J. (1997) Excitable Speech: A Politics of the Performative. New York, Routledge.

Castells, Manuel and Himanen, Pekka (2004) The Information Society and the Welfare State: The Finnish Model (Oxford: Oxford University Press).

Cohen, Saul Bernard (1964) Geography and World Politics in a Divided World (London: Methuen).

Connery, D. S. (1966) The Scandinavians (New York: Simon and Schuster).

Eglitis, D. S. (2004) Imagining the Nation. History, Modernity and Revolution in Latvia. Pennsylvania State University Press.

Engman, M. (2002) Lejonet och duppelörnen. Finlands imperiella decennier 1830-1890. Stockholm, Atlantis.

Greenfeld, L. (1995): Nationalism: five roads to modernity. Cambridge: Harvard University press.

Griffiths, T. (1993) Scandinavia (Wakefield Press).

Hadjú, Z. and Paasi, A. (1995) 'The Changing Representations of Finland in Geographical Texts in Hungary: A Contextual Analysis’, Fennia 173(1).

Hall, W. (1953) Green Gold and Granite: A Background to Finland (London: Max Parrish)

Hannula, J. O. (1939) Finland's War of Independence (London: Faber and Faber Limited)

Hanhimäki, J. M. (1997) Scandinavia and the United States. New York, Twayne Publishers.

Harle, V. and Moisio, S. (2000) Missä on Suomi? Kansallisen identiteettipolitiikan historia ja geopolitiikka [Where is Finland? The Nation's History of Identity Politics and Geopolitics] (Jyväskylä: Vastapaino)

Hechter, M. (2000): Containing Nationalism. Oxford University Press..

Hroch, M. (1985): Social preconditions of national revival in Europe : a comparative analysis of the social composition of patriotic groups among the smaller European nations. Cambridge: Cambridge University Press.

Huxley, S. D. (1990) Constitutionalist Insurgency in Finland. Finnish 'passive resistance' against russification as a case of nonmilitary struggle in the European resistance tradition (Helsinki: Suomen historiallinen seura).

Immonen, K. (1987): Ryssästä saa puhua... : Neuvostoliitto suomalaisessa julkisuudessa ja kirjat julkisuuden muotona 1918-39. Helsinki: Otava.

Jakobson, M. (1998) Finland in the New Europe (Westport, Connecticut: Praeger) 
Joenniemi, P. (2002) 'Finland in the New Europe: a Herderian or Hegelian project'. In L. Hansen and O. Waever (eds.) European Integration and National Identity. The Challenge of the Nordic States. London and New York, Routledge, pp. 182-213.

Joenniemi, P. (2003) ‘Can Europe Be Told from the North? Tapping into the EU’s Northern Dimension’. In F. Möller and S. Pehkonen (eds.) Encountering the North: Cultural Geography, International Relations and Northern Landscapes. Aldershot, Ashgate.

Jokisipilä, M. (2005) 'Suomalainen historiallinen myytti'. Tieteessä tapahtuu 2/2005, pp. 16-22.

Karemaa, O. (1998): Vihollisia, vainoojia, syöpäläisiä. Venäläisviha Suomessa 1917-1923. Helsinki: Suomen historiallinen seura.

Kekkonen, U. (1970) Neutrality: The Finnish Position. London, Heinemann.

Kemiläinen, A. (1998) Finns in the Shadow of the Aryans. Helsinki, Suomen Historiallinen Seura; Studia Historica 59.

Kettunen, P. (2001) 'The Nordic Welfare State in Finland', Scandinavian Journal of History 26(3).

Kivi, A. (1991) Seven Brothers (New Paltz: Finnish American Translators Association).

Klinge, M. (1993) The Finnish Tradition. Essays on structures and identities in the North of Europe. Helsinki, SHS.

Klinge, M. (1997) Keisarin Suomi. Espoo, Schildts.

Korhonen, K. (1969) 'Finland and the Soviet Union'. In I. Heiskanen, J. Huopaniemi, K. Korhonen and K. Törnudd (eds.) Essays on Finnish Foreign Policy. Vammala, Finnish Political Science Association.

Koskinen, Y. S. (1869): Oppikirja Suomen kansan historiasta. Helsinki: Suomalaisen Kirjallisuuden Seura

Kuisma, M. (2003) Consistent Continuity and Contingent Change: Globalisation, European Integration and the Paths of Citizenship in Finland and Norway. Unpublished PhD Thesis, University of Birmingham.

Laine, K. (1999) "Pääosassa Suomen kansa": Suomi-Filmin ja Suomen Filmiteollisuus kansallisen elokuvan rakentajina 1933-1939. Helsinki, SKS.

Lehti, M. (1999) A Baltic League as a Construct of the New Europe. Envisioning a Baltic Region and Small State Sovereignty in the Aftermath of the First World War. Frankfurt-am-Main, Peter Lang.

Lehti, M. (2000) 'Kansojen kilvoittelu kunniasta. Kansallisuusaatteen ja urheilun pyhä liitto', Historiallinen Aikakauskirja 3/2000, pp. 226-40.

Lehti, M. (2001) 'The Petersburgian Europe in Finnish Identity'. In P. Joenniemi (ed.) Saint Petersburg - Russian, European and Beyond. Saint-Petersburg University Press, pp. 3-20.

Lehti, M. (2002): 'Pohjoisen paluu. Uudet tarinat ja vanhat symbolit'. In eds. M. Heinonen etc.,Dialogus. Historian taito. Kirja-Aurora

Lehtonen, T. M. (1999) Europe's Northern Frontier: Perspectives on Finland's Western Identity. Jyväskylä, PS Kustannus. 
Liulevicius, V. (2000) War Land on the Eastern Front: Culture, National Identity, and German Occupation in World War I. Cambridge, Cambridge University Press.

Meinander, H. (1999) Tasavallan tiellä. Suomi kansalaissodasta 2000-luvulle. Espoo, Schildts.

Mikkeli, H. (2000) 'Metsäturkki ja sen jurot parturit. Näkemyksiä metsäluonnon ja kansaluonteen suhteesta 1800- ja 1900-luvuilla’. Historiallinen Aikakauskirja 3/2000.

Moisio, S. and Harle, V. (2002) Karhu poliittis-maantieteellisenä naapurina: kansallinen identiteettiprojekti 2000-luvun Suomessa. Turku, Turku University.

A Northern Dimension for the Policies of the European Union. A Video directed by P. Stenlund and M. Nissinen. Virtual Finland. virtual.finland.fi/finfo/english/northdim2.html.

Nousiainen, J. (1963) ‘The Parties and Foreign Policy’. In Finnish Foreign Policy. Helsinki, Finnish Political Science Association.

Paasi, A. (1996) Territories, Boundaries and Consciousness: The Changing Geographies of the FinnishRussian Border (Chichester: John Wiley and Sons)

Paasikivi, J. K. (1956) Paasikiven Linja I: Juho Kusti Paasikiven Puheita Vuosilta 1944-1956. Porvoo, WSOY.

Paasivirta, J. (1963): Finland och de olympiska spelen i Stockholm : diplomatin bakon kulisserna (Ekenäs)

Peuranen, E. (1995): 'Pietarin todellisuudet ja myytit’. In M. Lapola (ed.) Suomi \& Pierari. Helsinki: WSOY

Pihlaja, J. (1999) 'The Wild East begins just across the border', Helsingin Sanomat International Edition http://www.helsinki-hs.net/thisweek/43041999.html (23/10/1999).

Repo, E. and Melander, T. (2005) 'Finnish Information Technology in Good Form'. Available at http://virtual.finland.fi. Published April 2005 (downloaded 9 April 2005).

Ringmar, E. (1996) Identity, Interest and Action: A Cultural Explanation of Sweden's Intervention in the Thirty Years War. Cambridge, Cambridge University Press.

Roshwald, A. (2001) Ethnic Nationalism \& the Fall of Empires. Central Europe, Russia \& the Middle East, 1914-1923. London and New York, Routledge.

Ruokanen, T. (2004) Suomen menestyksen eväät: Tiekartta tulevaisuuteen. Helsinki,EVA.

Ruokanen, T. and Nurmio, A. (1995) Entä jos... Suomi ja mahdolliset maailmat. Porvoo, WSOY.

Salmi, H. and Kallioniemi, K. (2000) ‘Pohjan tähteiden tuolla puolen’. In H. Salmi and K. Kallioniemi (eds.) Pohjan tähteet. Populaarikulttuurin kuva suomalaisuudesta. Helsinki, Kirjastopalvelut).

Salokangas, R. (1996) 'The Finnish Broadcasting Company and the Changing Finnish Society, 1949-1966'. In R. Endén (ed.) Yleisradio 1926-1996: A History of Broadcasting in Finland. Helsinki, WSOY

Painolaistokset.

Shields, R. (1991) Places on the Margin: Alternative Geographies of Modernity (London: Routledge).

Smeds, K. (1996): Helsingfors-Paris : Finlands utveckling till nation på världsutställningarna 1851-1900 (Helsingfors: Svenska litteratursällskapet i Finland : Finska historiska samfundet) 
Smith, A.D. (2003): Chosen Peoples. Sacred Sources of National Identity (Cambridge: Cambridge University Press)

Tiilikainen, Teija (2006) 'Finland - An EU Member with a Small State Identity’, European Integration, 28:1, 73-87.

Valenius, J. (2004) Undressing the Maid. Gender, Sexuality and the Body in the Construction of the Finnish Nation. Helsinki, SKS.

Viljanen, V.M.J. (1920): Suomi, reunavallat ja Venäjän kysymys: talouspoliittinen tutkielma. Helsinki: Edistysseurojen kustannus

Wæver, O. (1992) 'Nordic Nostalgia: Northern Europe after the Cold War’, International Affairs 68(1).

Wæver, O. (2002) 'Identities, communities and foreign policy: Discourse analysis as foreign policy theory’. In L. Hansen and O. Wæver (eds.) Between Nations and Europe: Regionalism, Nationalism and the Politics of Union. London, Routledge.

Wiik, K. (2002) Eurooppalaisten juuret. Jyväskylä, Ateena.

Wilson, W. A. (1976) Folklore and Nationalism in Modern Finland. Bloomington, Indiana University Press. 